San Jose State University

SJSU ScholarWorks

Master's Theses

Master's Theses and Graduate Research

Summer 2016

\title{
Examining the Moderating Effect of Life Satisfaction on the Relationship between Perceived Underemployment and Job Attitudes among Millennials
}

Savannah M. Trakes

San Jose State University

Follow this and additional works at: https://scholarworks.sjsu.edu/etd_theses

\section{Recommended Citation}

Trakes, Savannah M., "Examining the Moderating Effect of Life Satisfaction on the Relationship between Perceived Underemployment and Job Attitudes among Millennials" (2016). Master's Theses. 4740. DOI: https://doi.org/10.31979/etd.2xq4-pua4

https://scholarworks.sjsu.edu/etd_theses/4740

This Thesis is brought to you for free and open access by the Master's Theses and Graduate Research at SJSU ScholarWorks. It has been accepted for inclusion in Master's Theses by an authorized administrator of SJSU ScholarWorks. For more information, please contact scholarworks@sjsu.edu. 


\title{
EXAMINING THE MODERATING EFFECT OF LIFE SATISFACTION ON THE RELATIONSHIP BETWEEN PERCEIVED UNDEREMPLOYMENT AND JOB ATTITUDES AMONG MILLENNIALS
}

\author{
A Thesis \\ Presented to \\ The Faculty of the Department of Psychology \\ San José State University \\ In Partial Fulfillment \\ of the Requirements for the Degree \\ Master of Science
}

by

Savannah M. Trakes

August 2016 
(C) 2016

Savannah M. Trakes

ALL RIGHTS RESERVED 
The Designated Thesis Committee Approves the Thesis Titled

EXAMINING THE MODERATING EFFECT OF LIFE SATISFACTION ON THE

RELATIONSHIP BETWEEN PERCEIVED UNDEREMPLOYMENT AND JOB

ATTITUDES AMONG MILLENNIALS

by

Savannah M. Trakes

APPROVED FOR THE DEPARTMENT OF PSYCHOLOGY

SAN JOSÉ STATE UNIVERSITY

August 2016

Dr. Megumi Hosoda Department of Psychology

Dr. Meghna Virick School of Management

Elizabeth Keller, M.A. Counselor Education 


\title{
ABTRACT \\ EXAMINING THE MODERATING EFFECT OF LIFE SATISFACTION ON THE RELATIONSHIP BETWEEN PERCEIVED UNDEREMPLOYMENT AND JOB ATTITUDES AMONG MILLENNIALS
}

\author{
By Savannah M. Trakes \\ Underemployment has been associated with negative attitudes and behaviors.
}

However, little research attention has been paid to identify variables that might moderate the relationship between underemployment and job attitudes. Given that Millennials are one of the groups most susceptible to underemployment, I examined the relationship between perceived underemployment and job attitudes (i.e., job satisfaction, intent to remain) using life satisfaction as a moderator among Millennial employees. Based on survey data from 552 Millennial employees across various sectors, results showed that perceived underemployment was negatively related to job satisfaction, intent to remain, and life satisfaction. Inconsistent with the prediction, life satisfaction did not moderate the relationship between perceived underemployment and these job attitudes. Strategies for employees and employers to minimize the negative impacts of perceived underemployment such as on-the job training or mentoring programs to learn new skills are suggested. 


\section{ACKNOWLEDGEMENTS}

First, I present my deepest thanks to my thesis advisor, Dr. Megumi Hosoda, for all of her guidance throughout the preparation of my thesis. Thank you Megumi, for helping me to become a better researcher. I would also like to thank Dr. Meghna Virick for her support and invaluable feedback. A special thanks also to my third reader, Elizabeth Keller, for her assistance helping me throughout this process. Finally, my very special appreciation to my husband, without your support, this thesis would not be accomplished. 


\section{TABLE OF CONTENTS}

LIST OF TABLES ...................................................................................... viii

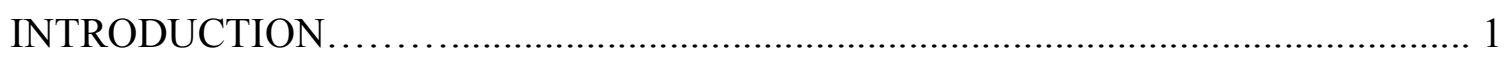

Definition and Measurement of Underemployment........................................ 4

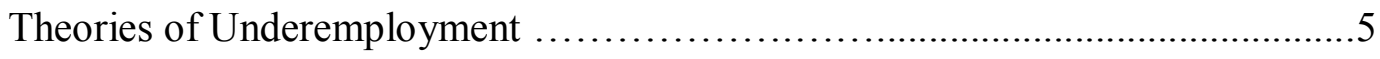

Emotional, Attitudinal, and Behavioral Outcomes of Underemployment............. 6

Variables that Moderate the Relationship Between Underemployment and

Outcomes.......................................................... 7

Life Satisfaction as a Potential Moderator...................................... 9

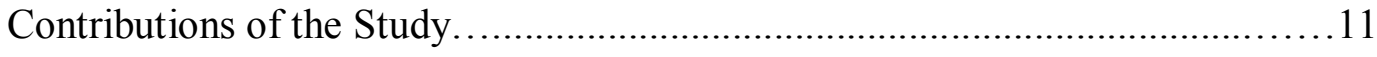

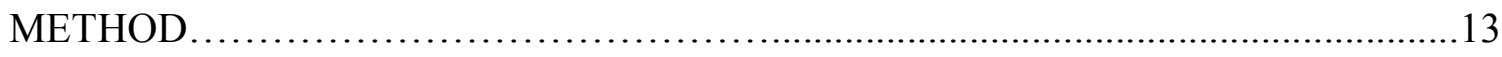

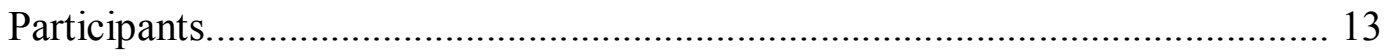

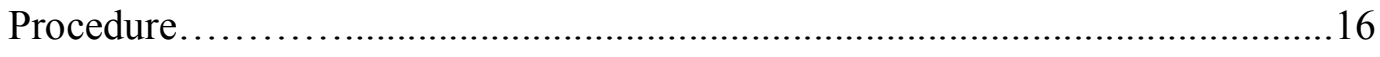

Measures.......................................................................... 16

Perceived underemployment...................................................... 16

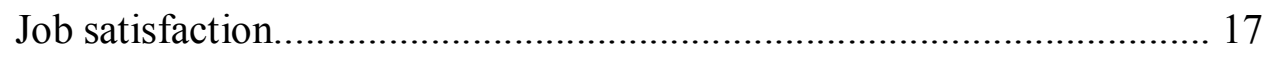

Intent to remain........................................................................ 17

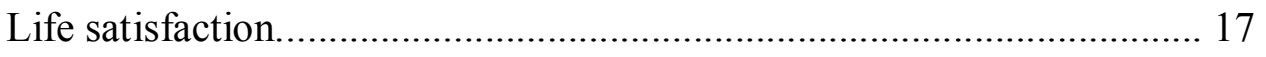

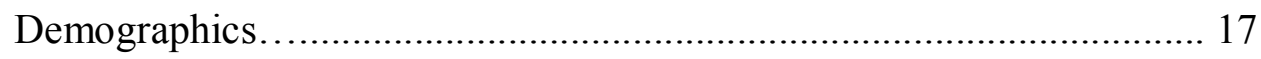

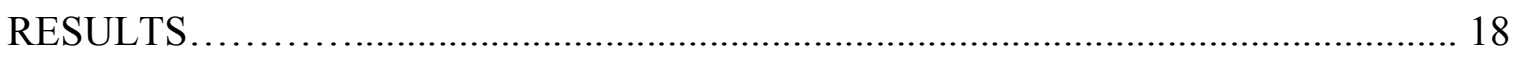

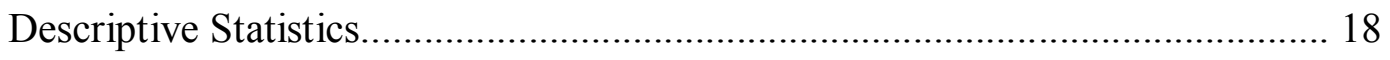

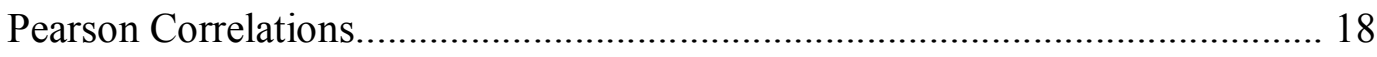

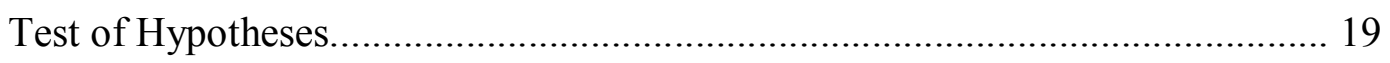




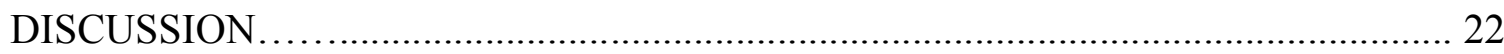

Implications of the Study....................................................................... 24

Strengths, Limitations, and Directions for Future Research............................ 25

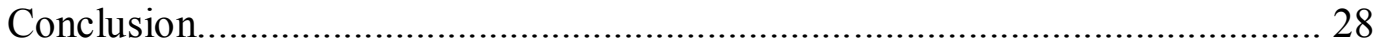

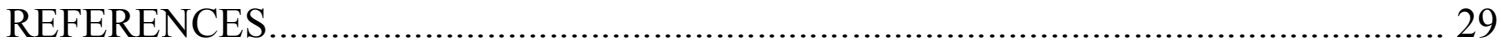

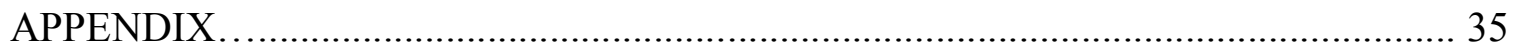




\section{LIST OF TABLES}

Table 1. Demographic Information......................................................................... 15

Table 2. Means, Standard Deviations, Pearson Correlations, and Reliabilities ................18

Table 3. Hierarchical Regression Summary for Variables Predicting Job Satisfaction ...20

Table 4. Hierarchical Regression Summary for Variables Predicting Intent to Remain...21 


\section{Introduction}

In past years, the economic downturn has had significant negative effects on the workforce across the globe. The unemployment rate, a common indicator of economic well-being, hit its peak in 2012 , reaching around $10 \%$ in both the United States (U.S.) and the European Union (Erdogan \& Bauer, 2009). By the end of 2014, the situation appeared to improve when the unemployment rate fell to $5.4 \%$ in the U.S. and to $5.9 \%$ in the United Kingdom (Bureau of Labor Statistics, 2014; EuroStat, 2014). However, even though the unemployment rate has been on the decline,

researchers (e.g., Taggart, 1982) argue that the rate of unemployment may not capture all aspects of inadequate employment or employment hardships. One example of inadequate employment is underemployment.

Underemployment is the situation in which individuals have qualifications such as education and skills that exceed the requirements of their position (Erdogan \& Bauer, 2009) or hold a job that is in some way inferior or of lower quality, relative to some standard (Maynard, Joseph, \& Maynard, 2006). Underemployment exists in every stratum of society, affecting not only lower level employees but executive-level employees as well (Feldman, Leana, \& Bolino, 2002). According to McKee-Ryan and Harvey (2011), underemployment is widespread across professions, and the prevalence of underemployment has been highest among individuals aged 18 to 29 and those without a college education, with underemployment rates of $28.9 \%$ and $23.1 \%$, respectively (Jacobe, 2011). A study of college graduates in their twenties indicates that $44 \%$ of them are stuck in low-wage or dead-end jobs, making this one of the highest rates of underemployment in decades (Abel, Deitz, \& Su, 2014), and the number of recent graduates making an annual salary lower than $\$ 25,000$ has also increased to the highest level since 1990 (Desilver, 2014). Although the unemployment rate has fallen to the lowest rate since 2008 (Bureau of Labor Statistics, 2014), Stahl 
(2015) indicates that this means very little to the Millennial generation, or those born between 1980 and 2000. Compared with prior generations, Millennials, even with increased likelihood of college education, continue to face some of the highest levels of underemployment (Peralta, 2014).

Some researchers suggest that the increase in overqualification among young adults may be the result of an increase in college educated workers which has exceeded the number of positions available for an educated workforce (Batenburg \& de Witte, 2001; Mottaz, 1984). Recent trend analyses indicate that the average level of education and the rates of overqualification have both been increasing in a positive linear direction (Ng \& Feldman, 2009; Vaisey, 2006). As the number of qualified job candidates continues to rise, the competition among them heightens, and some adequately qualified individuals may be forced into positions below what they are qualified for, simply because there are not enough positions to go around (Cable \& Hendey, 2007). Borghans and de Grip (2000) have labeled such phenomenon as "bumping down" or "crowding out," which is said to occur when the lesser educated workforce is forced to accept jobs below their skill level, because workers with higher levels of education are accepting lower level positions. Borghans and de Grip's research also suggests that when underemployment occurs early in one's career (e.g. new college graduates), it may lead to negative long-term attitudes regarding one's career as a whole.

The outcomes of underemployment have been examined and revealed that underemployment is related to unfavorable job outcomes such as reduced job satisfaction, affective commitment, and increased turnover intentions (Allen, \& van der Velden, 2001; Bolino \& Feldman, 2000; Feldman, 1996). More recently, researchers have tried to identify the variables that may moderate the relationship between underemployment and job attitudes and behaviors. For example, Erdogan and Bauer (2009) demonstrated that psychological empowerment moderated the relationship between perceived overqualification and job attitudes, voluntary turnover, and intent to 
remain such that the negative impact of perceived overqualification on job attitudes and behaviors occurred only when individuals were not psychologically empowered. When individuals were psychologically empowered, there was no relationship between perceived overqualification and these negative job attitudes. The Erdogan and Bauer study, indicates that psychological empowerment mitigates the negative effects of perceived overqualification on job satisfaction, intent to remain, and voluntary turnover. Given these findings, Erdogan and Bauer called for more studies to identify additional moderating variables. The current study attempted to contribute to the call for additional research by examining the role that life satisfaction may play as a moderating variable in the relationship between underemployment and negative job outcomes.

According to the RAND Employer Survey (2012), over half of all U.S. employers offer some sort of wellness promotion initiative, and in larger organizations, employers are more likely to offer complex wellness programs (Mattke et al., 2013). Due to the large number of business resources devoted to these programs such as employee assistance programs, recreational reimbursements, and the increasing work-life responsibilities placed on employees, it is appropriate to explore how an individual's life satisfaction outside of work may influence behavior in the workplace. The understanding that life satisfaction leads to a state of balance among one's experiences of meaning, pleasure, and engagement (Schueller \& Seligman, 2010), and that happier individuals are more likely to be engaged and to find meaning in both a work and personal capacity (Lyubomirsky, King, \& Diener, 2005) are key aspects to consider when examining workplace behavior. Although most individuals spend more than a third of their life in work-related activities (Van Zyl, Deacon, \& Rothmann, 2010), little research has examined how life satisfaction could hinder or enhance work constructs such as job satisfaction and intentions to remain among underemployed individuals in the workplace. Therefore, the present study attempted to examine 
whether life satisfaction would moderate the relationship between underemployment and job satisfaction and the relationship between underemployment and intention to remain among members of the Millennial generation.

The following sections provide the definition of underemployment, theories of underemployment, previous research findings on the consequences of underemployment, the role various moderators (e.g. employee empowerment, emotional support) play in the underemployment and job outcome relationship, and how life satisfaction might act as a moderator to these relationships. Finally, the hypotheses that were tested in the present study are presented.

\section{Definition and Measurement of Underemployment}

Individuals are said to be underemployed if they are (1) overeducated for their current job, (2) employed in a job outside of their field of study, (3) overqualified based on previous experience, (4) employed part-time but desire full-time employment, or (5) earn $20 \%$ lower wages than their previous job (Feldman, 1996). Underemployment can be objective or subjective. Objective underemployment is traditionally measured in comparison to an individual's previous job or those with similar education and experience. In contrast, subjective underemployment, or perceived underemployment, occurs when employees feel that their skills or abilities are not being fully utilized or that their knowledge or skills exceed the requirements of their current job (Khan \& Morrow, 1991). Thus, subjective underemployment relies on how individuals feel that their knowledge, skills, and abilities compare to the requirements of the job (Feldman; Khan \& Morrow). Khan and Morrow argue that subjective underemployment may have a greater effect on an individual's job attitudes and behaviors because of its alignment with the individual's perceptions of his or her current employment situation. Hence, the present study examined subjective 
underemployment or an individual's perception of being underemployed, rather than objective underemployment.

\section{Theories of Underemployment}

Several theories have been used to explain the negative consequences of underemployment, but person-job (P-J) fit theory (Kristof-Brown, Zimmerman, \& Johnson, 2005; Maynard et al., 2006) and relative deprivation theory (Feldman et al., 2002; Johnson \& Johnson, 2000; Johnson, Morrow, \& Johnson, 2002) have been the most dominant theoretical frameworks for underemployment. O'Rielly and Caldwell (2001) explain person-job fit (P-J fit) as a situation where an individual's knowledge, skills, or abilities (KSAs) align with the KSAs required to successfully complete the job. The P-J fit framework suggests that the greater the degree of perceived fit between the person and his or her job, the more the positive work outcomes will be (Kristof-Brown et al., 2005). In contrast, when the KSAs of individuals do not align with those of their jobs, these employees are less likely to be happy with their employment situations (KristofBrown et al.) and are expected to eventually leave the position for one which better matches their skill set (Lee \& Mitchell, 1994). In the context of underemployment, subjective underemployment or perceived underemployment can be considered a poor P-J fit because employees feel that they have more KSAs than a job requires.

Another theory that has been frequently used to explain the relationship between subjective underemployment and negative job outcomes is relative deprivation theory (Feldman et al., 2002; Johnson \& Johnson, 2000; Johnson et al., 2002). This theory postulates that an individual's thoughts and behaviors are dependent on his or her evaluation of the situation. Therefore, individuals may experience feelings of deprivation if their expectations of employment are not met, and may experience negative attitudes or behaviors if they feel that they are worse off compared to 
some standard (Smith, Pettigrew, Pippin, \& Bialosiewicz, 2001). Feldman et al. suggest that relative deprivation is relevant to the underemployment context because it allows employees to use their past, present, or future employment situations as a referent standard for comparing their current employment. Similarly, relative deprivation has also been used as a way to explain the reactions encountered by individuals in positions of underemployment (McKee-Ryan, \& Harvey, 2011). For example, in a study of re-employed executives, relative deprivation served as a mediator in explaining how underemployment led to decreased psychological well-being in reemployed individuals (Feldman et al.). Relative deprivation theory encompasses both the perception that a job is insufficient by some means, and the belief that the job should be better than it is. Thus, relative deprivation includes individuals wanting more and feeling more entitled than what jobs can provide (Feldman \& Turnley, 2004; McKee-Ryan, Virick, Prussia, Harvey, \& Lilly, 2009).

\section{Emotional, Attitudinal, and Behavioral Outcomes of Underemployment}

Research findings have been fairly consistent that both objective and subjective underemployment are associated with numerous negative outcomes for both employees and their employers (Bolino \& Feldman, 2000; Holtom, Lee and Tidd, 2002; Lee, 2005; Wald, 2005). It is, therefore, not surprising that underemployment has been gaining attention among academics. Research has consistently shown that underemployment leads employees to exhibit greater negative job attitudes and behaviors compared to their adequately employed counterparts (Bolino, \& Feldman; Johnson, \& Johnson, 2000; Peiro, Agut, \& Grau, 2010). For example, individuals who perceived themselves as overqualified for their jobs were less likely to be satisfied with their jobs (Bolino \& Feldman; Burke, 1977; Erdogan \& Bauer, 2009 Feldman, \& Turnley, 2004; Lee, 2005). Indeed, the most consistent research finding is that underemployment is associated with decreased 
job satisfaction (Feldman, 2011). In McKee-Ryan and Harvey's (2011) meta-analytic review of underemployment, they noted that underemployment was negatively related to overall job satisfaction with an average correlation of -.22 across 21 studies.

Furthermore, those who believe that they are underemployed are less likely to be satisfied with their pay and promotional opportunities (Khan \& Morrow, 1991), have higher turnover intentions (Feldman \& Turnley, 1995; Maynard et al., 2006; Wald, 2005), and are more likely to voluntarily leave their organization (Holtom et al., 2002; Verhaest, \& Omey, 2006). These findings hold true among a variety of individuals, including recent university graduates (Burke, 1997), nontenure track professors (Feldman, \& Turnley, 2004), university employees (Khan \& Morrow), and overseas expatriates (Bolino, \& Feldman, 2000; Lee, 2005).

Underemployment has been found to be positively linked to employee work alienation (Lee, 2005) and negatively related to job involvement (Burke, 1997; Feldman \& Turnley, 1995). Moreover, employees who reported themselves to be subjectively underemployed (McKee-Ryan et al., 2009), overqualified (Johnson et al., 2002; Maynard, et al., 2006), and relatively deprived (Feldman \& Turnely, 2004) felt that they had less of a reason to be committed to their current position than their adequately employed counterparts across various organizations (Leana \& Feldman, 1995). In sum, these findings clearly indicate the negative attitudinal and behavioral consequences for employees associated with underemployment.

\section{Variables That Moderate the Relationship Between Underemployment and Outcomes}

Although negative job attitudes and behaviors are the most common consequences of underemployment, an important gap in the underemployment literature is its relative lack of attention to variables that might moderate the relationship between underemployment and its outcomes (Erdogan \& Bauer, 2009). Identifying moderating variables is an important next step in 
the underemployment literature to help identify the factors that may ameliorate the negative effects traditionally associated with underemployment.

Several studies have begun to examine factors that might moderate the relationship between underemployment and job outcomes such as interesting work and fair treatment. For example, Wald (2005) found that when overqualified employees felt that their work was interesting or that they were being treated in a fair manner, their active pursuit of another job was reduced compared to their counterparts who felt their work was not interesting. Similarly, Erdogan and Bauer (2009) examined psychological empowerment as a moderator of the relationships between perceived overqualification and job satisfaction, intent to remain, voluntary turnover, and objective sales among a sample of 224 Turkish sales associates. Consistent with their hypotheses, results showed that psychological empowerment moderated the relationship between perceived overqualification and voluntary turnover, intent to remain, and job satisfaction. There was a negative relationship between perceived overqualification and these outcomes only when employees did not feel psychologically empowered and there was no relationship between them when employees reported higher levels of psychological empowerment. Furthermore, Johnson and Johnson (1997) also found that emotional support moderated the relationship between perceived overqualification and health such that the negative effect of perceived overqualification on health was smaller among those who received high emotional support compared to those perceiving low emotional support.

These results suggest that some variables (e.g., interesting work, psychological empowerment) attenuate the negative effects of underemployment on job attitudes and behaviors, and hence the negative consequences of underemployment could be avoided. Consequently, Anderson and Winefield (2011) have argued that more is needed to know about when 
underemployment matters and when its consequences are more likely to be positive or negative and called for more research on the identification of moderating variables.

\section{Life Satisfaction as a Potential Moderator}

Global life satisfaction or an individual's tendency to experience life in satisfying ways, has been defined as an individuals' cognitive evaluation of the positivity in their lives as a whole, based on their own set of standards (Shin \& Johnson, 1978). In a review of research, Frisch (1999) indicates that life satisfaction is not a byproduct of life events or factors (e.g., genetics, environmental factors), but it is an important indicating factor of life outcomes such as career, health, and interpersonal outcomes. Suldo and Huebner (2004) also indicate that adolescents with positive life satisfaction are less likely to develop externalizing behaviors in the face of stressful events compared to those who are dissatisfied with their lives. These findings indicate “...preliminary support that life satisfaction operates as a protective psychological strength that provides a buffer against some effects of adverse life events in adolescence," (Suldo, \& Huebner, p. 93).

Lazarus's (1991) transactional model of stress and coping has also been used as a framework for evaluating the process of coping with stressful events. Lazarus indicates that stress is experienced when an individual perceives that the demands of the situation exceed the personal and social resources the person is able to mobilize. Results of research by Jones-Johnson and Johnson (1992) reveal a significant positive relationship between underemployment and the five indexes of psychosocial stress, such that the more subjectively underemployed a person felt, the greater the individual's psychosomatic stress, frustration, hostility, depression, and insecurity (Jones-Johnson, 1989; Jones-Johnson \& Johnson). Lazarus and Cohen (1977) indicate that stressful events can be moderated by the individual's appraisal of the stressor and based on Lazarus's theory 
of stress and coping, life satisfaction may operate as a buffer or a moderator against the development of negative behaviors in stressful situations. Life satisfaction may mirror the general positive appraisal approach, which is theorized to influence the cognitive evaluations that are related to specific environmental events, and associated emotional and coping responses (Suldo, \& Huebner, 2004). A positive appraisal style may act to mitigate potentially negative events such that these negative experiences are seen in a more positive context which results in more positive behavioral and emotional reactions. Subsequently, when such an appraisal style is negative, this may predispose an individual to be more likely to experience negative emotions and behaviors.

To illustrate, even though the underemployed are more likely to be a poor fit for a given job and active job searchers, compared to their adequately employed counterparts (Wald, 2005), it is nevertheless possible that life satisfaction may serve as a buffer against the negative job outcomes typically associated with underemployment. The present study attempted to examine subjective underemployment as a life stressor that may be moderated by life satisfaction. One way to test whether or not life satisfaction may lessen the negative associations traditionally associated with underemployment is to assess its ability to function as a moderating variable in predictions of job satisfaction and turnover intentions in situations of underemployment. In this context, it would be expected that underemployed individuals with positive levels of life satisfaction would be less prone to experiencing job dissatisfaction and turnover intentions.

As mentioned earlier, Jones-Johnson and Johnson (1992) examined social and supervisor support as moderating variables on the relationship between subjective underemployment and psychosocial stress. Although these variables did not moderate the relationship, results of the study indicate that the greater the supervisor support, the less psychosocial stress the workers felt (JonesJohnson and Johnson). To the author's knowledge, no studies have examined life satisfaction as a 
moderator of the relationship between perceived underemployment and job attitudes. Therefore, this study seeks to better understand the role life satisfaction may play in alleviating the detrimental outcomes typically associated with underemployment. We suggest that individuals who achieve high levels of life satisfaction will have carry over effects into the workplace that act as a buffer against the negative job outcomes traditionally associated with underemployment. Thus, the purpose of this study was to test a moderational model of the effects of life satisfaction on the relationship between underemployment and subsequent outcomes among Millennials.

Hypothesis 1: Life satisfaction will moderate the relationship between perceived underemployment and job satisfaction among Millennial employees, such that when life satisfaction is low, there will be a negative relationship between perceived underemployment and job satisfaction. However, when individuals have high levels of life satisfaction, there will be no relationship between perceived underemployment and job satisfaction.

Hypothesis 2: Life satisfaction will moderate the relationship between perceived underemployment and intent to remain among Millennial employees, such that when life satisfaction is low, there will be a negative relationship between perceived underemployment and intent to remain. However, when individuals have high levels of life satisfaction, there will be no relationship between perceived underemployment and intent to remain.

\section{Contributions of the Study}

Limited research attention has been paid to identify boundary conditions or variables that may moderate the relationship between underemployment and job attitudes. The identification of boundary conditions are important because underemployment may not be associated with negative 
outcomes under certain situations. The present study expands the existing underemployment literature by 1) providing additional research around underemployment and the Millennial generation; 2) responding to calls for additional research to explore variables that may moderate the underemployment relationship (Erdogan \& Bauer, 2009); and 3) to better understand how an individual's overall life satisfaction may influence his or her attitudes and behaviors in the workplace. 


\section{Participants}

\section{Method}

A total of 696 individuals participated in the study. However, data from 68 participants were excluded from the analysis as they failed to respond to many items, and 76 participants were excluded because they did not meet the participation criteria. As an inclusion criterion, participants needed to be at least 18 years of age and employed at the time of data collection, resulting in responses from 552 individuals.

Table 1 depicts the demographic information of the participants. The sample consisted of 343 women (62.3\%) and 208 men (37.7\%). The majority of participants were aged between 18-20 years $(74.3 \%, n=410)$, followed by $21-29$ years $(22.5 \%, n=124)$, and $30-35$ years $(3.3 \%, n=18)$.

Participants identified themselves with a range of ethnicities such as Asian/Pacific Islander $(32.6 \%, n=180)$, Hispanic/Latino $(31.9 \%, n=176)$, White $(23.9 \%, n=132)$, Other $(7.2 \%, n=40)$, African American $(4.0 \%, n=22)$, and Native American $(0.4 \%, n=2)$. Most participants $(46.3 \%, n$ $=255$ ) identified themselves as second generation to the United States, followed by 104 participants (18.9\%) identifying as first generation, and the remainder of participants identified themselves as third generation or greater. The majority of respondents indicated a marital status of single, never married $(90.9 \%, n=501)$, followed by cohabitating with partner $(5.1 \%, n=28)$, married $(3.8 \%, n=$ $21)$, and divorced $(0.2 \%, n=1)$.

At the time of the survey, most respondents had achieved an education level of a bachelor's degree $(58.5 \%, n=323)$, followed by a high school diploma $(32.4 \%, n=178)$, associate's degree $(7.1 \%, n=39)$, master's degree $(1.3 \%, n=7)$, and doctoral degree $(0.7 \%, n=4)$. Part-time employment (77.0\%) was the most common employment situation of respondents, followed by fulltime $(15.9 \%)$ and temporary or contract employment $(7.1 \%)$. The number of years of total work experience ranged from less than one year to more than 10 years, with the majority of the 
respondents having 1 to 2 years of experience (42.2\%), followed by 2 to 4 years $(27.4 \%)$, less than 1 year $(14.3 \%), 4$ to 6 years $(9.2 \%)$, more than 10 years $(3.8 \%)$ and 6 to 10 years $(3.1 \%)$. 
Table 1

Demographic Information $(N=552)$

\begin{tabular}{lrr}
\hline Demographics & $n$ & $\%$ \\
\hline Gender & & \\
Women & 343 & $62.3 \%$ \\
Men & 208 & $37.7 \%$ \\
Age & & \\
$18-20$ years & 410 & $74.3 \%$ \\
$21-29$ years & 123 & $22.5 \%$ \\
$30-35$ years & 18 & $3.3 \%$ \\
& & \\
Ethnicity & & \\
African American & 22 & $4.0 \%$ \\
Asian / Pacific Islander & 180 & $32.6 \%$ \\
Hispanic / Latino & 176 & $31.9 \%$ \\
Native American & 2 & $0.4 \%$ \\
White & 131 & $23.9 \%$ \\
Other & 40 & $7.2 \%$
\end{tabular}

Generation to the U.S.

First generation

Second generation

$104 \quad 18.9 \%$

Third generation

$254 \quad 46.3 \%$

Fourth generation

$27 \quad 4.9 \%$

$48 \quad 8.7 \%$

Fifth generation

$81 \quad 14.7 \%$

Unknown

$37 \quad 6.5 \%$

Marital Status

Single, never married

Cohabiting with partner

Married

Divorced

$\begin{array}{rr}501 & 90.9 \% \\ 28 & 5.1 \% \\ 21 & 3.8 \% \\ 1 & 0.2 \%\end{array}$

Education Level

High school diploma

$\begin{array}{rr}178 & 32.4 \% \\ 39 & 7.1 \% \\ 323 & 58.5 \% \\ 7 & 1.3 \% \\ 4 & 0.7 \%\end{array}$

Associate's degree

Bachelor's degree

Master's degree

Doctorate degree

$4 \quad 0.7 \%$

Employment Situation

Full-Time

$88 \quad 15.9 \%$

Part-Time

$424 \quad 77.0 \%$


Years of Work Experience

Less than 1 year

$79 \quad 14.3 \%$

1 to 2 years

$232 \quad 42.2 \%$

2 to 4 years

$151 \quad 27.4 \%$

4 to 6 years

$51 \quad 9.2 \%$

6 to 10 years

$17 \quad 3.1 \%$

More than 10 years

$21 \quad 3.8 \%$

\section{Procedure}

Data were collected using an online survey, and distributed to individuals meeting the criteria using the researcher's personal contacts, professional networks, and a research participant pool from a state university located in Northern California. Upon starting the online survey, participants were provided with a short description of the study and were required to provide their consent to participate. The survey commenced with questions about current employment status, and the next section inquired about the participants' attitudes towards their current job. This section consisted of items about perceptions of underemployment, job satisfaction, intent to remain, and overall life satisfaction. The last set of questions asked about demographic information such as age, gender, ethnicity, marital status, and generational status to the United States. Following the submission of responses, participants were thanked for their participation and the survey ended.

\section{Measures}

Perceived underemployment. Perceived underemployment was measured with 10 items from Johnson et al.'s (2002) Perceived Overqualification scale. A 5-point Likert-type rating ranging from 1 (strongly disagree) to 5 (strongly agree) was used. Sample items include "I have mastered nearly every aspect of my job," and "My work experience is more than necessary to do my present job." Higher scores indicate that participants perceive themselves as more underemployed. Cronbach's coefficient alpha was .79 , indicating that the scale has good internal consistency. 
Job satisfaction. Job satisfaction was measured with three items from Cammann, Fichman, Jenkins, and Klesh's (1979) study. The items were measured on a 5-point Likert-type scale ranging from 1 (strongly disagree) to 5 (strongly agree) and include "I like working at this organization," "In general I like my job," and "All in all, I am satisfied with my job." Higher scores indicate that participants are more satisfied with their current job. Cronbach's coefficient alpha was .90 , indicating that the scale has high internal consistency.

Intent to remain. Intent to remain was measured with two items from Adams and Beehr's (1998) study. Responses were captured on a 5-point Likert-type rating scale ranging from 1 (strongly disagree) to 5 (strongly agree). Items include "I will probably look for a new job in the next year," and "I often think about leaving this organization." Higher scores indicate that participants have a greater intention to remain at their current job. Cronbach's coefficient alpha was .73 , indicating that the scale has good internal consistency.

Life satisfaction. Life satisfaction was measured with five items from Diener, Emmons, Larsen, and Griffin (1985). Participants responded to the items on a 5-point Likert-type scale ranging from 1 (strongly disagree) to 5 (strongly agree). Sample items include "So far I have gotten the important things I want in life," and "In most ways my life is close to my ideal." Higher scores indicate that participants are more satisfied with the conditions of their life. Cronbach's coefficient alpha was .85 , indicating that the scale has high internal consistency.

Demographics. Participants were asked to answer eight questions on their demographic information. Items included age, gender, ethnic background, marital status, highest level of education completed, and generational status to the United States. 


\section{Results}

\section{Descriptive Statistics}

Table 2 presents the means, standard deviations, Pearson correlations, and Cronbach's alphas of the measured variables. On a 1-5 point scale, participants perceived themselves as being somewhat underemployed $(M=3.11, S D=.51)$. Furthermore, they were relatively satisfied with their jobs $(M=3.63, S D=.94)$, somewhat intended to remain at their current job $(M=2.64, S D=$ $.99)$, and had moderate levels of life satisfaction $(M=3.16, S D=.80)$.

Table 2

Means, Standard Deviations, Pearson Correlations, and Reliabilities $(N=552)$

\begin{tabular}{|c|c|c|c|c|c|c|}
\hline Demographics & $M$ & $S D$ & 1 & 2 & 3 & 4 \\
\hline $\begin{array}{l}\text { 1. Perceived } \\
\text { underemployment }\end{array}$ & 3.11 & .51 & $(.79)$ & & & \\
\hline 2. Job satisfaction & 3.63 & .94 & $-.37 * *$ & (.90) & & \\
\hline 3. Intent to remain & 2.64 & .99 & $-.45 * *$ & $.59 * *$ & $(.73)$ & \\
\hline 4. Life satisfaction & 3.16 & .80 & $-.02 *$ & $.25 * *$ & $.17 * *$ & $(.85)$ \\
\hline
\end{tabular}

Note: $* p<.05 * * p<.01$

Reliability coefficients (alpha) appear on the diagonal

\section{Pearson Correlations}

As can be seen from Table 2, perceived underemployment was negatively related to job satisfaction $(r=-.37, p<.01)$, intent to remain $(r=-.45, p<.01)$, and life satisfaction $(r=-.02, p<$ $.05)$. That is, the more underemployed participants felt, the less they were satisfied with their jobs, the less likely they were to remain in their jobs, and the less satisfied they were with their lives.

Job satisfaction was significantly related to intent to remain $(r=.59, p<.01)$, and had a significant positive relationship with life satisfaction $(r=.25, p<.01)$. These findings show that respondents who were satisfied with their jobs were more likely to remain at their current job and to have increased feelings of life satisfaction. There was also a positive relationship between intent to 
remain and life satisfaction $(r=.17, p<.01)$. However, the correlations among the variables were weak to moderate.

\section{Tests of Hypotheses}

Hypothesis 1 stated that life satisfaction would moderate the relationship between perceived underemployment and job satisfaction such that when life satisfaction was high, there would be no relationship between perceived underemployment and job dissatisfaction; however, when life satisfaction was low, the relationship between perceived underemployment and job satisfaction would be negative. Hypotheses 2 stated that life satisfaction would moderate the relationship between perceived underemployment and intent to remain such that when life satisfaction was high, there would be no relationship between perceived underemployment and intent to remain but when life satisfaction was low, the relationship between perceived underemployment and job satisfaction would be negative.

In order to examine the potential moderating role of life satisfaction, a hierarchical regression analysis was performed for each variable. In each hierarchical regression analysis, perceived underemployment was entered in Step 1, life satisfaction in Step 2, and finally, the product of perceived underemployment and life satisfaction as the interaction term was entered in Step 3. If the variance explained by the interaction between perceived underemployment and life satisfaction is statistically significant, this indicates a significant interaction effect.

The first model evaluated whether life satisfaction would moderate the relationship between perceived underemployment and job satisfaction. Table 3 shows the results of the hierarchical regression analysis. The analysis revealed that perceived underemployment was a significant predictor of job satisfaction and accounted for $14 \%$ of the variance in job satisfaction, $R^{2}=.14$, $R^{2} a d j=.14, F(1,550)=87.89, p<.001$. This indicates that respondents who had high levels of 
underemployment were more likely to be dissatisfied with their jobs. Next, life satisfaction accounted for an additional $6 \%$ of the variance in job satisfaction above and beyond the variance explained by perceived underemployment, $\Delta R^{2}=.06, F(2,549)=68.34, p<.05$. Millennials who had high levels of life satisfaction were more likely to be satisfied with their jobs above and beyond feeling underemployed. Results of Step 3 in the hierarchical regression analysis showed that the interaction term accounted for an additional $1 \%$ of the variance in job satisfaction above and beyond the variance explained by perceived underemployment and life satisfaction, $\Delta R^{2}=.01, F(3$, $548)=47.45, p>.05$ but it was not statistically significant. Therefore, life satisfaction did not moderate the relationship between perceived underemployment and job satisfaction. These results show that Hypothesis 1 was not supported.

Table 3

Hierarchical Regression Summary for Variables Predicting Job Satisfaction

\begin{tabular}{lllll}
\hline Steps and Predictor Variables & $\beta$ & $R 2$ & $\Delta R 2$ & $R$ \\
\hline $\begin{array}{l}\text { Step 1: } \\
\quad \text { Perceived underemployment }\end{array}$ & $-.37^{* * *}$ & $.14^{* *}$ & $.14^{* *}$ & $.37^{* *}$ \\
$\begin{array}{l}\text { Step 2: } \\
\quad \text { Life satisfaction }\end{array}$ & $.25^{* * *}$ & $.20^{* *}$ & $.06^{*}$ & $.45^{* *}$ \\
$\begin{array}{l}\text { Step 3: } \\
\quad \begin{array}{l}\text { Perceived underemployment x } \\
\quad \text { Life satisfaction }\end{array}\end{array}$ & $.53^{*}$ & $.21 * *$ & .01 & .46 \\
\hline
\end{tabular}
Note: $* p<.05, * * p<.01, * * * p<.001$. Betas reported at time of entry.

The second model assessed the moderating effect of life satisfaction on the relationship between perceived underemployment and intent to remain. Table 4 presents the results of the hierarchical regression analysis. The analysis showed that perceived underemployment was a significant predictor of intent to remain and accounted for $20 \%$ of the variance in intent to remain, $R^{2}=.20, R^{2} a d j=.20, F(1,550)=139.76, p<.001$. This indicates that respondents who had higher levels of underemployment were less likely to intend to remain in the organizations. Next, life 
satisfaction accounted for additional $3 \%$ of the variance in intent to remain above and beyond the variance explained by perceived underemployment, $\Delta R^{2}=.03, \Delta F(2,549)=83.19, p<.001$. These findings show that employees who had high levels of life satisfaction were more likely to remain at their organizations above and beyond their perceptions of underemployment. In the third step of this hierarchical regression analysis, the interaction term did not account for an additional significant proportion of the variance in intent to remain above and beyond the variance explained by perceived underemployment and accurate job preview, $\Delta R^{2}=.001, \Delta F(3,548)=55.71, p<.001$. Therefore, Hypothesis 2 was not supported.

Table 4

Hierarchical Regression Summary for Variables Predicting Intent to Remain

\begin{tabular}{lllll}
\hline Steps and Predictor Variables & $\beta$ & $R 2$ & $\Delta R 2$ & $R$ \\
\hline $\begin{array}{l}\text { Step 1: } \\
\text { Perceived underemployment }\end{array}$ & $-.45^{* * *}$ & $.20^{* * *}$ & $.20^{* * *}$ & $.45^{* * *}$ \\
$\begin{array}{l}\text { Step 2: } \\
\quad \text { Life satisfaction }\end{array}$ & $.17^{* * *}$ & $.23 * * *$ & $.03 * * *$ & $.48^{* * *}$ \\
$\begin{array}{l}\text { Step 3: } \\
\quad \begin{array}{l}\text { Perceived underemployment x } \\
\text { Accurate job preview }\end{array}\end{array}$ & -.22 & $.23^{*}$ & .00 & $.48^{*}$ \\
\hline
\end{tabular}
Note: $* p<.05, * * p<.01, * * * p<.001$. Betas reported at time of entry. 


\section{Discussion}

Underemployment has been identified as a pervasive problem for both employers and employees (Feldman \& Maynard, 2011), with Millennials being one of the most susceptable generations to underemployment (Abel et al., 2014). However, research on the relationship between perceived underemployment and job attitudes among Millennials and recent college graduates is scarce. The examination of perceived underemployment among this particular group is important as the Millennial generation has now become the most educated generation in U.S. history, but is also the generation anticipated to face the most widespread underemployment (Peralta, 2014). It is also important to understand how these early career experiences build the foundation for job experiences and expectations throughout one's career and if moderator variables exist to lessen the negative consequences of underemployment. Therefore, the current study was conducted to examine the relationship between perceived underemployment and job attitudes in a sample of Millennial employees while also examining life satisfaction as a potential moderator of the relationship between perceived underemployment and job attitudes. It is argued that based on Lazarus's (1991) theory of coping and stress, life satisfaction may interact with the experience of stressful events (i.e., perceived underemployment) to predict subsequent thoughts and behaviors (i.e., job satisfaction and intentions to remain). This may prove particularly beneficial to employees of the Millennial generation who have been considered the most susceptable generation to underemployment (Abel et al., 2014).

Consistent with past research, results of this study show that employees who perceived themselves as more underemployed had lower levels of job satisfaction and intentions to remain. These findings are consistent with Burke (1997) and Feldman and Turnley (1995) who examined the relationship between perceived underemployment and job satisfaction among recent business 
school graduates. If employees perceive themselves to be underemployed, it is likely that they experience lower job satisfaction and lower levels of intentions to remain, probably because the terms or rewards of employment are inadequate for them. One new consequence of perceived underemployment revealed by the present study is a negative relationship between perceived underemployment and life satisfaction such that people may become less satisfied with their own lives when they find themselves in positions of perceived underemployment.

Although it was hypothesized that life satisfaction would moderate the relationship between perceived underemployment and job satisfaction and the relationship between perceived underemployment and intent to remain, results did not support these hypotheses. Life satisfaction did not act as a moderator of the relationship between perceived underemployment and these job attitudes. An explanation for these findings could be that the Millennial employees in the sample did not feel highly underemployed; therefore, it did not matter whether or not they were highly satisfied with their lives, they still felt satisfied with their jobs. Another explanation for the lack of the interaction effect could be that because Millennial employees are still the early stages of their lives and careers, they may have not yet experienced many of the personal values that make up the framework for life satisfaction (e.g. love, family, money, career, religion, material items). The majority of respondents (84\%) were employed in only a part-time or temporary capacity, and nearly $91 \%$ of the respondents were single and never married. Therefore, the levels of life satisfaction in our sample may have not been varied enough to moderate the relationship. 


\section{Implications of the Study}

The current study provided additional support for the relationship between perceived underemployment and job satisfaction and perceived underemployment and intent to remain (Burris, 1983; Feldman et al., 2002; Khan \& Morrow, 1991). Perceived underemployment was negatively related to both job satisfaction and intent to remain such that Millennial employees who perceived themselves as underemployed experienced lower levels of job satisfaction and intent to remain. These results support findings that perceived underemployment reduces job satisfaction and intent to remain.

Although the moderating role of life satisfaction on the relationship between perceived underemployment and job attitudes was not supported, life satisfaction was found to be negatively related to perceived underemployment. Workers in the sample who experienced lower levels of life satisfaction also experienced higher levels of perceived underemployment or vice versa.

One of the most important implications of the current study is that the finding that the negative relationship between perceived underemployment and life satisfaction might indicate that employees become less satisfied with their own lives when they are in positions of perceived underemployment. Employees should increase their awareness of the negative implications of underemployment not only on their workplace attitudes but the negative implications underemployment may have on their satisfaction of life as well.

The current study also has some practical implications for organizations that employ underemployed individuals. This study found that perceived underemployment was negatively related to job satisfaction and intent to remain. Therefore, it is important that organizations seek to better understand the negative implications of perceived underemployment and take measures

against it. Given the potential negative consequences associated with perceived underemployment, 
it is important for organizations to address the issue of underemployment within their workforce. On-the-job training or mentoring is a low cost option that organizations may wish to consider to enhance their workforce. This may be especially beneficial for the underutilized or underemployed workforce as these particular employees typically have additional capability or capacity. With workplace mentoring or on-the-job training, these workers might contribute to the success of the organization. These on-the-job training and mentoring programs are likely to be beneficial for individuals as they improve their knowledge, skill set or professional growth and the organization will benefit from increased contributions with the same number of resources. It is essential that organizations understand the skill set and capacity of their workforce, as there may be untapped potential available to respond to business demands within their current underutilized or involuntarily part-time workforce. These kinds of practices are likely to help companies expand the capacity of employees who are inclined to perceive underemployment in their current work situation.

\section{Strengths, Limitations, and Directions for Future Research}

One strength of this study is that perceived underemployment was examined among Millennial employees. Millennials, especially in the United States, are at a greater risk of being underemployed than Generation X (those born during the late 1960s and 1970s) and Baby Boomers (those born between the end of World War 2, 1945 and the late 1960s). For example, Peralta (2014) has shown that nearly $30 \%$ of Millennials with a medical degree are underemployed, compared to $22 \%$ of Gen Xers and $21 \%$ of baby boomers. Although Millennials are now the most educated generation of the U.S. workforce, they also face the highest levels of underemployment (Peralta). However, research on perceived underemployment among Millennials is relatively sparse. Burke (1997) and Feldman and Turnley (1995) each studied underemployment among 
recent college graduates, however, at the time these studies were conducted, the oldest of individuals in the Millennial generation would have not yet reached university and would have not been included in the studies. Underemployment among recent college graduates was pervasive then (Burke, 1997; Feldman \& Turnley, 1995), but may be even more prevalent now. The most significant contribution of this study is that it adds upon previous findings in a sample of Millennial employees. The current study also reveals the negative relationship between perceived underemployment and life satisfaction. To the author's knowledge, this is the first study to examine such relationship. An additional strength of the study is the relatively large sample size which is likely to increase statistical power of the results. Finally, the ethnic diversity of respondents in the sample help to make the results more generalizable across both gender and race.

Like most other research, this study also holds several limitations. First, the sample used in this study came from a single university, which may hinder the results from being generalizable to the wider population. Since the responses were collected from students and graduates of a single university the results represent only a subset of the population specific to the university sampled and its surrounding employers. It would be better to gather data from a sample of Millennial employees across many universities and segments of the country. Moreover, the sample mainly consisted of Millennials employed in a part-time or temporary capacity. Employees in a full-time capacity could be exposed to perceived underemployment in differing levels. Full time employees may more fully associate themselves with their careers which may lead to stronger workplace sentiments. Therefore, a sample that is more varied in terms of employment status may yield different results in examining perceived underemployment among Millennials.

Secondly, data were collected through a self-report survey tool and the use of self-report measures may increase common method variance (Podsakoff, MacKenzie, Lee \& Podsakoff, 2003). 
However, several measures in the study such as perceived underemployment and life satisfaction require the perceptions of the employee rather than objective measures and are required to be collected as self-report. To minimize the potential effects of common method variance in the study, it would have been preferable to introduce a time lag between the measurement of perceived underemployment and perceptual outcomes (Erdogan \& Bauer, 2009). Future studies could also examine underemployment in its objective form with employee performance reviews and job qualifications rather than just self-report measures. Objective underemployment takes into consideration an individual's actual skills and knowledge as compared with the requirements of the job to determine if underemployment exists, rather than relying solely on the opinion of the employee.

The current study was not intended to examine causality between the constructs and consequently, the lack of causality is another limitation of this study. Therefore, it is unknown whether perceived underemployment causes one to feel that they have lower levels of job satisfaction or if having lower levels of job satisfaction may have led to the increase in perceived underemployment. To solve for this problem, future research should incorporate an element of interviewing into the sample to help understand and establish cause and effect between perceived underemployment and job satisfaction. Another remedy may be to utilize a longitudinal study when underemployment and job attitudes are measured longitudinally.

Finally, this study measured job attitudes, however, future study could measure both performance in-role and extra-role performance. Behaviors such as performance are important to study because these types of outcomes are directly related to how an employee behaves both positively and negatively in the workplace. Similar to the views of Erdogan and Bauer (2009), it is recommend that future research to further explore the moderator variables that may ameliorate the 
relationship between perceived underemployment and negative job outcomes. As the negative implications of underemployment are widely known, research to further explore moderator variables that may reduce these unpleasant outcomes is still needed. Future studies may wish to consider incorporating a measure of awareness, or intent for accepting a position of underemployment into their model of moderation. Furthermore, underemployment research on the Millennial generation would also be useful to further the underemployment literature and to understand how underemployment early in one's career may shape their thoughts and feelings around the workplace as their career progresses.

\section{Conclusion}

In an attempt to further examine possible moderating variables of underemployment, the present study examined the relationship between perceived underemployment and job attitudes and posited life satisfaction as a possible moderator of these relations among Millennial employees. Findings of the study revealed that the sample perceived underemployment to be experienced at moderate levels, and that perceived underemployment was negatively related to job satisfaction, intent to remain, and life satisfaction. However, when examined as a moderating variable, life satisfaction did not moderate the relationship between underemployment and job satisfaction or the relationship between underemployment and intent to remain. An important implication of this research is that it supports past research that perceived underemployment has negative consequences for both employees and organizations and it extends that perceived underemployment also relates to life outside of work life. Employers can look to identify those who may be in positions of underemployment and tap into the underutilized capacity of these workers. By providing additional challenges and training or mentorship opportunities, employers and 
underemployed employees may have the opportunity to further expand the capabilities of the underemployed workforce and this may lead to benefits for both employees and organizations. 


\section{References}

Abel, J., Deitz, R., \& Su, Y. (2014). Are recent college graduates finding good jobs? Federal Reserve Bank of New York: Current Issues in Economics and Finance, 20, 1-8. Retrieved from http://journalistsresource.org/studies/economics/jobs/recent-college-graduatesemployment-underemployment

Adams, G. A., \& Beehr, T. A. (1998). Turnover and retirement: a comparison of their similarities and differences. Personnel Psychology, 51, 643-665. doi:10.1111/j.17446570.1998.tb00255.x

Allen, J., \& Van der Velden, R. (2001). Educational mismatches versus skill mismatches: effects on wages, job satisfaction, and on-the-job search. Oxford Economic Papers, 53, 434-452. doi:10.1093/oep/53.3.434

Anderson, S., \& Winefield, A. H. (2011). The impact of underemployment on psychological health, physical health, and work attiudes. In Maynard, D.C., and Feldman, D.C. (1), Underemployment, psychological, economic and social challenges (pp. 165-185). New York: Springer. doi:10.1007/978-1-4419-9413-4_9

Batenburg, R., \& de Witte, M. (2001). Underemployment in the Netherlands: How the Dutch 'Poldermodel' failed to close the education-jobs gap. Work, Employment \& Society, 15, 7394. doi:10.1017/S0950017001000046

Bolino, M. C., \& Feldman, D. C. (2000). The antecedents and consequences of underemployment among expatriates. Journal of Organizational Behavior, 21, 889-911. Retrieved from http://www.jstor.org/stable/3100360

Borghans, L., \& de Grip, A. (2000). Low wages, skills and the utilization of skills. The Overeducated Worker? The Economics of Skill Utilization (pp. 191-202). Northampton Massachusetts: Edward Elgar Publishing Limited.

Bureau of Labor Statistics. (2014). How the Government Measures Unemployment. Retrieved from: http://www.bls.gov/cps/cps_htgm.htm

Burke, R. J. (1997). Correlates of under-employment among recent business school graduates. International Journal of Manpower, 18, 627-635. doi:10.1108/01437729710186455

Burris, B. H. (1983). The human effects of underemployment. Society for the Study of Social Problems, 31, 96-110. doi:10.2307/800412

Cable, D. M., \& Hendey, D. (2010). What to do with the overqualified candidate? Human Resources Magazine. 14, 8-22. Retrieved from: http://www.hrinz.org.nz/Site/HR_Info/Knowledge_Base/HR_Delivery_/Performance_Mana 
gement_Info/Performance_Mgt_Articles/What_to_do_with_the_Overqualified_Candidate.a $\operatorname{spx}$

Cammann, C., Fichman, M., Jenkins, G. D., \& Klesh, J. R. (1983). Assessing the attitudes and perceptions of organizational members. In S. E. Seashore, E. E. Lawler III, P. H. Mirvis, \& C. Cammann (Eds.), Assessing organizational change: A guide to methods, measures and practices (pp. 71-138). New York: John Wiley and Sons.

Desilver, D. (2014). 5 facts about today's college graduates. Pew Research Center. Retrieved from: http://www.pewresearch.org/fact-tank/2014/05/30/5-facts-about-todays-college-graduates

Diener, E., Emmons, R. A., Larsen, R. J., \& Griffin, S. (1985). The satisfaction with life scale. Journal of Personality Assesment, 49, 71-75. Retreived from: http://www.fetzer.org/sites/default/files/images/stories/pdf/selfmeasures/SATISFACTIONSatisfactionWithLife.pdf

Erdogan, B., \& Bauer, T. N. (2009). Perceived overqualification and its outcomes: The moderating role of empowerment. Journal of Applied Psychology, 94, 557-565. doi:10.1037/a0013528

EuroStat. (2014). Unemployment rate by sex and age groups: Monthly average. Retrieved from: http://ec.europa.eu/eurostat/en/web/products-datasets/-/UNE_RT_M

Feldman, D. C. (1996). The nature, antecedents and consequences of underemployment. Journal of Management, 22, 385-407. doi:10.1177/014920639602200302

Feldman, D. C., Leana, C. R. , \& Bolino, M. C. (2002). Underemployment and relative deprivation among re-employed executives. Journal of Occupational and Organizational Psychology, 75, 453-471. doi:10.1348/096317902321119682

Feldman, D. C., \& Maynard, D. C. (2011). A labor economic perspective on overqualification. Industrial and Organizational Psychology, 4, 233-235. doi:10.1111/j.17549434.2011.01331.x

Feldman, D. C., \& Turnley, W. H. (1995). Underemployment among recent business college graduates. Journal of Organizational Behavior, 16, 691-706. doi:10.1002/job.4030160708

Feldman, D. C., \& Turnley, W. H. (2004). Contingent employment in academic careers: Relative deprivation among adjunct faculty. Journal of Vocational Behavior, 64, 284-307. doi: 10.1016/j.jvb.2002.11.003

Frisch, M. B. (1999). Quality of life assessment/intervention and the Quality of Life Inventory (QOLI). In Maruish, M. E. (Ed.), The Use of Psychological Testing for Treatment Planning 
and Outcome Assessment (pp. 1227-1331). Hillsdale, NJ: Lawrence Erlbaum Associates Publishers.

Holtom, B. C., Lee, T. W., \& Tidd, S. T. (2002). The relationship between work status congruence and work related attitudes and behaviors. Journal of Applied Psychology, 87, 903-915. doi:10.1037/0021-9010.87.5.903

Jacobe, D. (2011). Gallup finds U.S. underemployment stuck at 185\% in mid-Sept. Gallup. Retrieved from: http://www.gallup.com/poll/149525/Gallup-Finds-UnderemploymentStuck-Mid-Sept.aspx

Johnson, G. J. \& Johnson, W. R. (1997). Perceived overqualification, emotional support, and health. Journal of Applied Social Psychology, 27, 1906-1918. doi:10.1111/j.15591816.1997.tb01631.x

Johnson, G. J. \& Johnson, W. R. (2000). Perceived overqualification and dimensions and job satisfaction: A longitudinal analysis. Journal of Psychology, 134, 537-555. doi: $10.1080 / 00223980009598235$

Johnson, W. R., Morrow, P. C., \& Johnson, G. J. (2002). An evaluation of a perceived overqualification scale across work settings. The Journal of Psychology, 136, 425- 441. doi: $10.1080 / 00223980209604169$

Jones-Johnson, G. J. (1989) Underemployment, underpayment and psychological stress among working black men. The Western Journal of Black Studies, 13, 57-65.

Jones-Johnson, G. J. \& Johnson, W. R. (1992) Subjective underemployment and psychosocial stress: The Role of perceived social and supervisor support. The Journal of Social Psychology, 132, 11-21. doi:10.1080/00224545.1992.9924684

Khan, L. J., \& Morrow, P. C. (1991). Objective and subjective underemployment relationships to job satisfaction. Journal of Business Research, 22, 211-218. doi:10.1016/01482963(91)90002-F

Kristof-Brown, A. L., Zimmerman, R. D., \& Johnson, E. C. (2005). Consequences of individuals' fit at work: A meta-analysis of person-job, person-organization, person-group, and personsupervisor fit. Personnel Psychology, 58, 281-342. doi:10.1111/j.1744-6570.2005.00672.x

Lazarus, R. S. (1991). Progress on a cognitive-motivational-relational theory of emotion. American Psychologist, 46, 819-834. Retrieved from: http://dx.doi.org/10.1037/0003-066X.46.8.819 
Lazarus, R. S., \& Cohen, J. B. (1977). Environmental Stress. In I. Altman. \& J. F. Wohlwill. (Eds.), Human Behavior and Environment: Advances in theory and research (pp. 89-127). New York: Springer US. doi:10.1007/978-1-4684-0808-9_3

Leana, C. R., \& Feldman, D. C. (1995). Finding new jobs after a plant closing: Antecedents and outcomes of the occurrence and quality of reemployment. Human Relations, 48, 1381-1401. doi:10.1177/001872679504801201

Lee, C. H. (2005). A study of underemployment among self-initiated expatriates. Journal of World Business, 40, 172-187. doi:10.1016/j.jwb.2005.02.005

Lee, T. W., \& Mitchell, T. R. (1994). An alternative approach: The unfolding model of voluntary employee turnover. Academy of Management, 19, 51-89.

doi:10.5465/AMR.1994.9410122008

Lyubomirsky, S., King, L., \& Diener, F. (2005). The benefits of frequent positive affect: Does happiness lead to success? Psychological Bulletin, 131, 80-85. doi:10.1037/00332909.131.6.803

Mattke, S., Liu, H. S., Caloyeras, J. P., Huang, C. Y., Van Busum, K. R., Khodyakov, D., \& Shier, V. (2013). Workplace Wellness Programs Study: Final Report. Santa Monica, CA: RAND Corporation. Retrieved from: http://www.rand.org/pubs/research_reports/RR254.html

Maynard, D. C., Joseph, T. A., \& Maynard, A. M. (2006). Underemployment, job attitudes, and turnover intentions. Journal of Organizational Behavior, 27, 509-536. doi:10.1002/job.389

McKee-Ryan, F.M., \& Harvey, J. (2011). “I have a job, but ...”: A review of underemployment. Journal of Management, 37, 962-996. doi:10.1177/0149206311398134

McKee-Ryan, F.M., Virick, M., Prussia, G.E., Harvey, J., \& Lilly, J.D. (2009). Life after the layoff: getting a job worth keeping. Journal of Organizational Behavior, 30, 561-580. doi:10.1002/job.566

Mottaz, C. (1984). Education and work satisfaction. Human Relations, 37, 985-1004. doi: $10.1177 / 001872678403701107$

O'Reilly, C. A., \& Caldwell, C. J. (1991). People and organizational culture: A profile comparison approach to assessing person-organization fit. Academy of Management Journal, 32, 487516. doi: $10.2307 / 256404$

Ng, T. W. H., \& Feldman, D. C. (2009). Age, work experience, and the psychological contract. Journal of Organizational Behavior, 30, 1053-1075. doi:10.1002/job.599 
Peralta, K. (2014). Millennials still aren't there yet. US News and World Report. Retrieved from: http://www.usnews.com/news/articles/2014/11/18/millennials-still-arent-there-yet-in-thejob-market

Peiro, J.M., Agut, S., \& Grau, R. (2010) The relationship between overeducation and job satisfaction among young Spanish workers: The role of salary, contract of employment, and work experience. Journal of Applied Social Psychology, 40, 666-689. doi:10.1111/j.15591816.2010.00592

Podsakoff, P. M., MacKenzie, S. B., Lee, J., and Podsakoff, N. P (2003). Common method biases in behavioral research: A critical review of the literature and recommended remedies. Journal of Applied Psychology, 88, 879-903. doi:10.1037/0021-9010.88.5.879

Schueller, S., \& Seligman, M. (2010). Pursuit of pleasure, engagement, and meaning: Relationships to subjective and objective measures of well-being. The Journal of Positive Psychology, 5, 253-263. doi:10.1080/17439761003794130

Shin, D. C., \& Johnson, D. M. (1978). Avowed happiness as an overall assessment of the quality of life. Social Indicators Research, 5, 475-492. doi:10.1007/BF00352944

Smith, H. J., Pettigrew, T. F., Pippin, G. M., \& Bialosiewicz, S. (2001). Relative deprivation a theoretical and meta-analytic review. Personality and Social Psychology Review, 16, $203-$ 232. doi:10.1177/1088868311430825

Stahl, A. (2015). The 5.4\% unemployment rate means noting for millennials. Forbes. Retrieved from: http://www.forbes.com/sites/ashleystahl/2015/05/11/the-5-4-unemployment-ratemeans-nothing-for-millennials/

Suldo, S., \& Huebner E.S. (2004). Does life satisfaction moderate the effects of stressful life events on psychopathological behavior during adolescence? School of Psychology Quarterly, 19, 93-105. doi:10.1521

Taggart, R. (1982). The hardship consequences of labor market problems. In What's happening to American labor force productivity measurements? (pp. 41-76). Kalamazoo, MI: W.E. Upjohn Institute for Employment Research. doi:10.17848/9780880994149

Vaisey, S. (2006). Education and its discontents: Overqualification in America, 1972-2002. Social Forces, 85, 835-864. doi:10.1353/sof.2007.0028

Van Zyl, L., Deacon, E., \& Rothmann, S. (2010). Towards happiness: experiences of work-role fit, meaningfulness and work engagement of industrial organisational psychologists in 
South Africa. SA Journal of Industrial Psychology, 36, 10-20. Retrieved from:

http://www.scielo.org.za/scielo.php?script=sci_arttext\&pid=S2071-

07632010000100014\&lng=en\&tlng=en

Verhaest, D., \& Omey, E. (2006). The impact of overeducation and its measurement. Social Indicators Research, 77, 419-448. Retrieved from:

http://link.springer.com/article/10.1007/s11205-005-4276-6\#

Wald, S. (2005). The impact of overqualification on job search. International Journal of Manpower, 26, 140-156. doi:10.1108/01437720510597649 


\section{Appendix}

Survey Items

Perceived Overqualification (Johnson, Morrow, \& Johnson, 2002)

1. My formal education overqualifies me for my present job.

2. My work experience is more than necessary to do my present job.

3. Frankly, I am overqualified for the job I hold.

4. My talents are not fully utilized on my job.

5. I have mastered nearly every aspect of my job.

6. Some continuing education related to my job would improve my job performance.

7. My job frequently provides me with new challenges.

8. My job provides me with the opportunity to learn new things.

9. The day-to-day content of my job seldom changes.

10. My job has a lot of potential for change and growth.

Job Satisfaction (Cammann, Fichman, Jenkins, \& Klesh, 1979)

1. I like working at this organization.

2. In general I like my job.

3. All in all, I am satisfied with my job.

Intent to Remain (Adams, \& Beehr, 1998)

1. I often think about leaving this organization.

2. I will probably look for a new job in the next year.

Satisfaction with Life (Diener, Emmons, Larsen \& Griffin, 1985)

1. In most ways my life is close to my ideal.

2. The conditions of my life are excellent.

3. I am satisfied with my life.

4. So far I have gotten the important things I want in life.

5. If I could live my life over, I would change almost nothing. 